\title{
Textbook Evaluation: An Analysis of Listening Comprehension Parts in Top Notch 2A \& 2B
}

\author{
Afshin Soori (Corresponding author) \\ Department of Foreign Languages, Larestan Branch, Islamic Azad University, Larestan, Iran \\ E-mail: Afshin_soori@yahoo.com \\ Elham Haghani \\ Department of Foreign Languages, Larestan Branch, Islamic Azad University, Larestan, Iran \\ E- mail: haghanielham@yahoo.com
}

Doi:10.7575/aiac.alls.v.6n.5p.183

URL: http://dx.doi.org/10.7575/aiac.alls.v.6n.5p.183
Received: 27/05/2015

Accepted: 01/08/2015

\begin{abstract}
Textbooks are the instruments that assist both teachers and learners in process of second language learning. With respect to the importance of textbooks in a language course, evaluation of course books is a significant issue for most researchers. The present study investigated and analyzed Listening Comprehension parts in Top Notch $2 \mathrm{~A} \& 2 \mathrm{~B} 2^{\text {nd }}$ edition. Top Notch 2A \& 2B have 10 Units. The number of listening comprehension parts is in the range of 2 to 4 parts in each unit through the book. So the number of listening comprehension parts is not equally distributed. The participants of this study are 10 EFL teachers of two English language Institutes in Jahrom. Strong and weak aspects of Listening Comprehension parts have indicated in this research. The weaknesses involve the pictures and visuals are not clear enough to enhance students' motivation and interest, the audio is not completely suitable for students' English level, and Discussion parts are not stimulating students' talking. Furthermore this study revealed the crucial function of teachers in listening achievement of students.
\end{abstract}

Keywords: textbook evaluation, listening comprehension, ELT

\section{Introduction}

Evaluation is systematic collecting information for purposes of decision making. It involves gathering information on patterns of language use, language ability, and attitudes toward language. In language program evaluation, evaluation is the decisions about the quality of curriculum or materials program. (Longman Dictionary of Language teaching \& Applied Linguistics, 2002, page.188).Evaluation means paying attention to both the results of a course, and the designing and performing of the course. The aim of evaluation is to examine the course achievement and where it requires improvement. (Nation \& Macalister, 2010, p.123).

Many researchers try to find strengths and weaknesses in every teaching material in order to take advantage of the former and anticipate the latter. (Ur, 2012, p.203). In every language teaching classroom, course books have significant role in the process of learning and teaching. Course books refer to the materials which are used as the basis for courses. (Ur, 2012, p.197).

As Nation \& Macalister (2010) mentioned in adapting an existing course book, teachers may wish to add some changes to it. For doing this the teaching material must suit the interests and proficiency of learners. The existing course book should have comprehensible input ("interesting comprehensible receptive activity in both listening and reading"). Also the course book must contain fluency both in receptive and productive skills. (p. 161-2).

In every language course students spend plenty of time and money passing the course. Therefore it is worthwhile to evaluate the course book in a systematic way. In the beginning of every evaluation process, the teacher considers the essential features of evaluation procedure which are "right vocabulary and grammar level for learners, focus on language and skills, certain price of book, readily availability of book, appropriate size and number of lessons according to length of course, and not offend religious or cultural sensitivities of learners". (Nation \& Macalister, 2010, p. 165).

Comprehension is the ability of understanding the meaning of every spoken or written communication. Listening comprehension is a prerequisite for speaking skills. The focus of comprehension is on understanding meaning. (Longman Dictionary of Language teaching \& Applied Linguistics, 2002, page.99).Students should first learn to listen and comprehend, then produce the language. Listening comprehension is the process of understanding and realizing speech. In listening comprehension process linguistic items (phonemes, words, grammatical structures), and topics, language situations, listeners' background knowledge have significant roles. (Chastain,1988, p.205). It is crystal clear that in language learning, the learner should first understand then speak the language. Therefore in a listening comprehension task as we expect students to comprehend everything, it is necessary to give them a meaningful context. (Chastain,1988, p.192). 
Among different characteristics of every comprehension listening task, there are important points to consider in this present research. In Comprehension Listening, topics and contexts are important. The topics and contexts should be relevant to background knowledge of students. The topics must be based on students' daily lives. Listening comprehension tasks should have real-language situations. Ready-made learning tasks can suit the appropriate level of learners. Learning tasks are the major base of communicative practice. They are essential for improving fluency and accuracy of four skills (speaking, listening, reading, and writing) in communicative situations. (Ur, 2012, p. 198 \& 202). The speed of speech in every listening comprehension should be normal and moderate. The speed should accommodate students' levels. (Chastain,1988, p.190, 195\&200).

Chastain (1988) pointed out that Pre-Listening activities have the most important effect on any listening comprehension."The type and number of unknown linguistic forms and vocabulary items undoubtedly affect the students' ability to complete the listening comprehension activity satisfactorily." (p. 201). Therefore it is a good idea to give students unknown linguistic forms in order to teach them new things.

Post-Listening or Follow-up activities give students feedback. These activities can be individual, pair work and group work. Discussions, role plays, and writing assignments are other parts of post-listening activities. (p. 203).

Ur (2012) reported different types of listening activities like ticking off items (students listen to a speech, then mark correct items), cloze ( the text has some gaps and students have to write down the missing words), answering questions (students write down the answers while they listen the text), note- taking (students take brief notes from a speech). (p.109 \& 110).

Ur (2012) asserted that listening activities involve reading, writing, or speaking. So accomplishing listening activities demands a combination of skills. (p.109). In Discussion parts which are like speaking activities, making a careful choice of topic and task stimulate interest, motivation, interaction, and participation among learners. In Pair work and Group work the amount of learner talk will increase. As students are often afraid of talking in front of classroom, Pair work and Group work can raise their participation. Role plays can be done in pairs or groups. Role play is the only way of practicing real-life interactions in classroom, so it is a useful technique for developing confidence and cooperation between students. (Ur, 2012, p. 118, 119 \& 1206).

\section{Review of literature}

As Chastain (1988) mentioned there was a traditional view that listening process could not be visible, so it was a passive skill. But recent studies about mind recognized listening as an active process. (p.193).The importance of listening comprehension skills has been ignored by language teachers and students. They did not notice the necessity of improving listening comprehension skills as prerequisite for speaking skills. (Chastain,1988, p.192). New studies show that Listening improves language competence of learners. (Longman Dictionary of Language teaching \& Applied Linguistics, 2002, page.313). Students should be professional in listening, since they have to answer the questions at the same time. Therefore it is more useful for learners to listen for the main idea, or important information. (Ur, 2012, p.102).

According to the researches about textbook evaluation, the checklist of present study is based on different available checklists. The researcher took sample of several various checklists for example Miekley (2005), Mukundun, Nimehchisalem \& Hajimohammadi (2011), and Saricoban and Can (2012).

A study by Rezaee, Kouhpaeenejad \& Mohammadi (2012) which evaluated and compared Top Notch $2^{\text {nd }}$ and Interchange $3^{\text {rd }}$ edition, the results showed a balance of activities in both series. The activities provide enough meaningful practice, include individual, pair, and group work. Regarding to subject and content, Top Notch series revealed more powerful.

Another research by Mohammadi \& Abdi (2014) investigated positive and negative points of Top Notch series. The findings displayed that teachers confirmed it as a suitable basis for language learning, and enhancing students' interest in English study.

The aim of present study is to analyze the listening comprehension parts in Top Notch 2A \& 2B which are used in some English Language Institutes in Jahrom. Top Notch 2A \& 2B have 10 Units. Every Unit of this book has some Listening Comprehension parts. The number of listening comprehension parts is in the range of 2 to 4 parts in each unit through the book. So the number of listening comprehension parts is not equally distributed. The components of listening comprehension parts in this book are Yes/No questions, True/False; complete statements, make notes, match, pictures, Pair work, Discussions, Group work, Role play, and writing. Most of the listening comprehension parts in this book involve a combination of listening and writing skills (as Chastain, (1988, p.202) stated this aspect of listening comprehension parts). For example the book wants learners to complete the sentences, fill in blanks, answer True/False questions, put check marks, and write classroom assignments. These activities will strengthen both listening and writing abilities of the learners.

\section{Research questions}

Here are some questions that will be answered in this study:

Q1: Do the Listening Comprehension parts have essential characteristics of an efficient listening Comprehension?

Q2: What types of Tasks and Activities are used in Listening Comprehension parts?

Q3: Are the types of Tasks and Activities useful for enhancing listening skills?

\section{Method}

4.1 Participants

The population of this study is 10 EFL teachers of two English language Institutes in Jahrom. 
These English Language Institutes are Jahad-E-Daneshgahi and Navid of Jahrom branch. The participants are 5 male and 5 female teachers. They are at the age of 28 to 46 . Their teaching experience ranges from 4-12 years.

4.2 Instruments

As the instrument the researcher used a checklist which is based on the available checklists. The checklist has three main parts which are A) Generally, B) Activities \& Tasks, C) Follow-up Tasks (Post-listening). It has 22 questions. For the first 20 questions, the participants had to choose among 1,2,3,4 points. ( $1 \& 2$ represent low points, $3 \& 4$ represent high points), so it is a 4-point scale. The last 2 questions had three items of $\mathrm{A}, \mathrm{B}, \mathrm{C}$ to choose.

4.3 Procedure

This study carried out for the purpose of analyzing Listening Comprehension parts in Top Notch 2A \& 2B. Finding the strengths and weaknesses of Listening Comprehension parts was the dominant aim of it. Another objective of this study was to search the roles of teacher and book in listening comprehension achievement of learners. The quantitative analysis of this study involves Frequencies, Percentages, and Means of 20 items, but for the last 2 questions (21 \& 22) the researcher has just examined qualitatively.

\section{Results}

The results of each part on the checklist have been illustrated in some tables. The Frequencies and Percent of every question have been measured and indicated in a single table. Questions 1 to 9 are belong to the first part (Generally) of the checklist.

Table 1 - Q1

\begin{tabular}{|l|l|l|l|l|}
\hline Frequency & percent & Valid percent & Cumulative percent & \\
\hline 2 & 20.0 & 20.0 & 20.0 & low \\
3 & 30.0 & 30.0 & 50.0 & low \\
4 & 40.0 & 40.0 & 90.0 & high \\
1 & 10.0 & 10.0 & 100.0 & high \\
10 & 100.0 & 100.0 & Total \\
\hline Table 2-Q2 & \multicolumn{4}{|l|}{} \\
\hline Frequency & percent & Valid percent & Cumulative percent & \\
\hline 1 & 10.0 & 10.0 & 10.0 & low \\
3 & 30.0 & 30.0 & 40.0 & low \\
6 & 60.0 & 60.0 & 100.0 & high \\
10 & 100.0 & 100.0 & & Total \\
\hline
\end{tabular}

Table 3-Q3
\begin{tabular}{|l|l|l|l|l|}
\hline Frequency & percent & Valid percent & Cumulative percent & \\
\hline 1 & 10.0 & 10.0 & 10.0 & low \\
7 & 70.0 & 70.0 & 80.0 & low \\
2 & 20.0 & 20.0 & 100.0 & high \\
10 & 100.0 & 100.0 & & Total \\
\hline
\end{tabular}

\begin{tabular}{|c|c|c|c|c|}
\hline \multicolumn{5}{|l|}{ Table $4-\mathrm{Q} 4$} \\
\hline Frequency & percent & Valid percent & Cumulative percent & \\
\hline 6 & 60.0 & 60.0 & 60.0 & low \\
\hline 3 & 30.0 & 30.0 & 90.0 & high \\
\hline 1 & 10.0 & 10.0 & 100.0 & high \\
\hline 10 & 100.0 & 100.0 & & Total \\
\hline
\end{tabular}

\begin{tabular}{|c|c|c|c|c|}
\hline \multicolumn{5}{|l|}{ Table 5-Q5 } \\
\hline Frequency & percent & Valid percent & Cumulative percent & \\
\hline 2 & 20.0 & 20.0 & 20.0 & low \\
\hline 6 & 60.0 & 60.0 & 80.0 & high \\
\hline 2 & 20.0 & 20.0 & 100.0 & high \\
\hline 10 & 100.0 & 100.0 & & Total \\
\hline
\end{tabular}

Table 6-Q6
\begin{tabular}{|l|l|l|l|l|}
\hline Frequency & percent & Valid percent & Cumulative percent & \\
\hline 1 & 10.0 & 10.0 & 10.0 & low \\
3 & 30.0 & 30.0 & 40.0 & low \\
4 & 40.0 & 40.0 & 80.0 & high \\
2 & 20.0 & 20.0 & 100.0 & high \\
10 & 100.0 & 100.0 & & Total \\
\hline Table 7-Q7 & \multicolumn{4}{|l|}{} \\
\hline Frequency & percent & Valid percent & Cumulative percent & \\
\hline 1 & 10.0 & 10.0 & 10.0 & low \\
3 & 30.0 & 30.0 & 40.0 & low \\
5 & 50.0 & 50.0 & 90.0 & high \\
1 & 10.0 & 10.0 & 100.0 & high \\
10 & 100.0 & 100.0 & & Total \\
\hline
\end{tabular}




Table 8-Q8
\begin{tabular}{|l|l|l|l|l|}
\hline Frequency & percent & Valid percent & Cumulative percent & \\
\hline 1 & 10.0 & 10.0 & 10.0 & low \\
2 & 20.0 & 20.0 & 30.0 & low \\
6 & 60.0 & 60.0 & 90.0 & high \\
1 & 10.0 & 10.0 & 100.0 & high \\
10 & 100.0 & 100.0 & Total \\
\hline Table 9-Q 9 & percent & Valid percent & Cumulative percent & \\
\hline Frequency & 10.0 & 10.0 & 10.0 & low \\
\hline 1 & 50.0 & 50.0 & 60.0 & low \\
5 & 40.0 & 40.0 & 100.0 & high \\
4 & 100.0 & 100.0 & & Total \\
\hline 10 & &
\end{tabular}

According to table 1-9, in the first question 50 percent of participants chose high points and $50 \%$ selected low. $60 \%$ participants preferred high points for Q2, Q6 and Q7. In question three 80\% selected low points. 60\% chose low in Q4 and Q9. Question five shows $80 \%$ high. For question eight $70 \%$ chose high points.

Table 10-Part A . Generally

\begin{tabular}{|l|l|l|l|l|l|l|l|l|l|}
\hline Q1 & Q2 & Q3 & Q4 & Q5 & Q6 & Q7 & Q8 & Q9 & \\
\hline 10 & 10 & 10 & 10 & 10 & 10 & 10 & 10 & 10 & valid \\
0 & 0 & 0 & 0 & 0 & 0 & 0 & 0 & 0 & Missing \\
2.4000 & 2.5000 & 2.3000 & 2.5000 & 3.0000 & 2.7000 & 2.6000 & 2.7000 & 2.3000 & Mean \\
.96609 & .70711 & .94868 & .70711 & .66667 & .94868 & .84327 & .82327 & .67495 & Std. \\
1.00 & 1.00 & 1.00 & 2.00 & 2.00 & 1.00 & 1.00 & 1.00 & 1.00 & Deviation \\
4.00 & 3.00 & 4.00 & 4.00 & 4.00 & 4.00 & 4.00 & 4.00 & 3.00 & Minimum \\
24.00 & 25.00 & 23.00 & 25.00 & 30.0 & 27.00 & 26.00 & 27.00 & 23.00 & Maximum \\
& & & & & & & & & Sum \\
\hline
\end{tabular}

Table 10 displays the Means of part A of the checklist. Based on this table, Q3 and Q9 have the least Mean (2.3), but Q5 has the most Mean (3.0) among these 9 questions. It shows that Q5 received the highest points while Q3 and Q9 got the lowest.

Table $11-$ Q 10

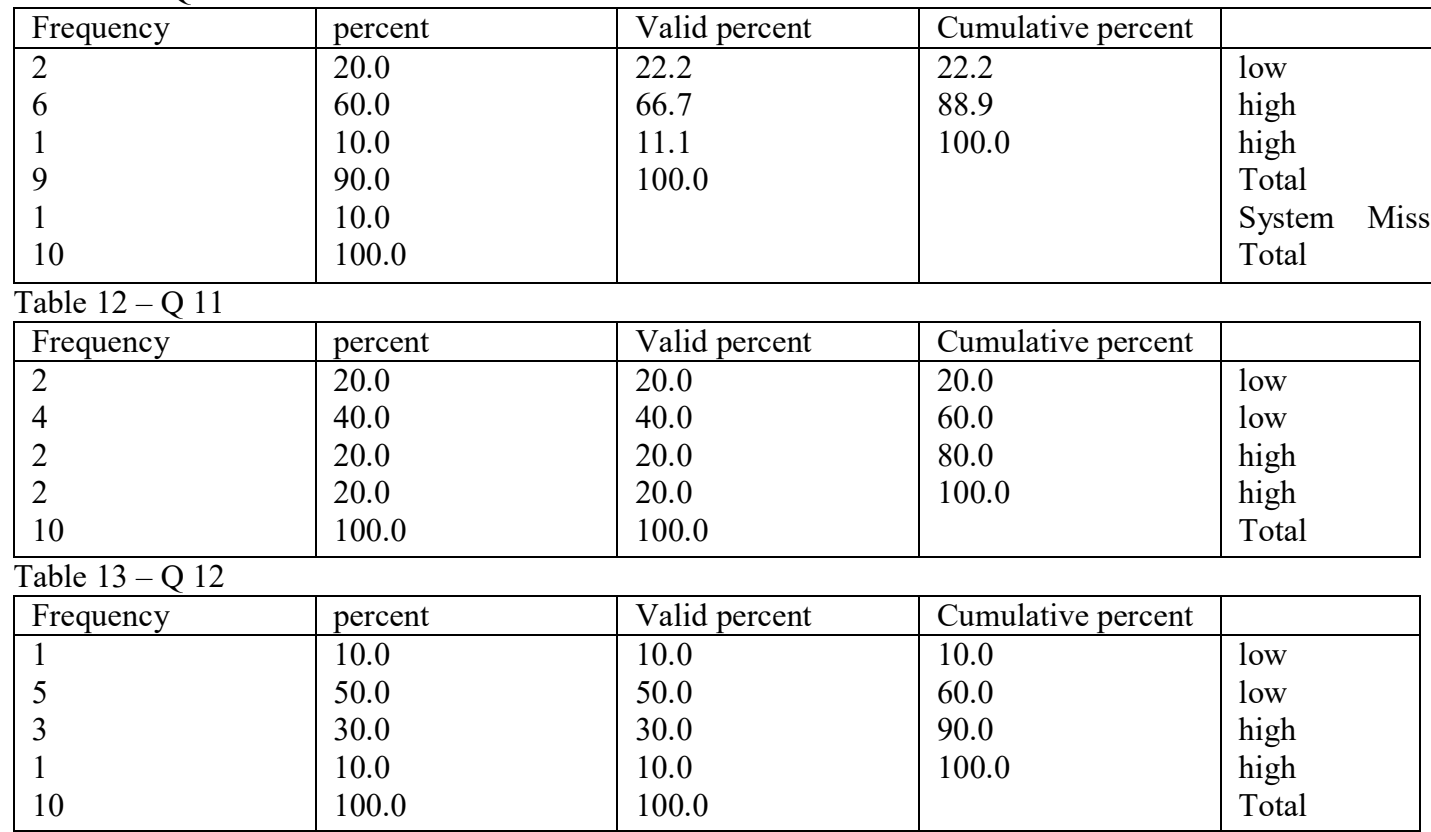

Tables 11-13 represent that Q11 (one missing answer for question 11) and Q12 have 60\% low points while Q10 have $70 \%$ high. 
Table 14 - part B. Activities \& Tasks

\begin{tabular}{|l|l|l|l|}
\hline Q10 & Q11 & Q12 & \\
\hline 9 & 10 & 10 & Valid \\
1 & 0 & 0 & Missing \\
2.8889 & 2.4000 & 2.4000 & Mean \\
.60093 & 1.07497 & .84327 & Std. Deviation \\
2.00 & 1.00 & 1.00 & Minimum \\
4.00 & 4.00 & 4.00 & Maximum \\
26.00 & 24.00 & 24.00 & Sum \\
\hline
\end{tabular}

As table 14 illustrates Q10 has the most Mean amongst these three questions. This shows that most of participants selected high points for question number 10 .

Table $15-\mathrm{Q} 13$

\begin{tabular}{|c|c|c|c|c|}
\hline Frequency & percent & Valid percent & Cumulative percent & \\
\hline 2 & 20.0 & 20.0 & 20.0 & low \\
\hline 8 & 80.0 & 80.0 & 100.0 & high \\
\hline 10 & 100.0 & 100.0 & & Total \\
\hline \multicolumn{5}{|c|}{ Table $16-$ Q14 } \\
\hline \begin{tabular}{|l|} 
Frequency \\
\end{tabular} & percent & Valid percent & Cumulative percent & \\
\hline 5 & 50.0 & 50.0 & 50.0 & low \\
\hline 5 & 50.0 & 50.0 & 100.0 & high \\
\hline 10 & 100.0 & 100.0 & & Total \\
\hline \multicolumn{5}{|c|}{ Table 17-Q 15} \\
\hline \begin{tabular}{|l|} 
Frequency \\
\end{tabular} & percent & Valid percent & Cumulative percent & \\
\hline \begin{tabular}{|l|l|l|}
1 & \\
\end{tabular} & 10.0 & 10.0 & 10.0 & low \\
\hline 3 & 30.0 & 30.0 & 40.0 & low \\
\hline 6 & 60.0 & 60.0 & 100.0 & high \\
\hline 10 & 100.0 & 100.0 & & Total \\
\hline \multicolumn{5}{|c|}{ Table 18-Q16 } \\
\hline \begin{tabular}{|l|} 
Frequency \\
\end{tabular} & percent & Valid percent & Cumulative percent & \\
\hline 6 & 60.0 & 60.0 & 60.0 & low \\
\hline 3 & 30.0 & 30.0 & 90.0 & high \\
\hline 1 & 10.0 & 10.0 & 100.0 & high \\
\hline 10 & 100.0 & 100.0 & & Total \\
\hline
\end{tabular}

Table 19-Q17

\begin{tabular}{|l|l|l|l|l|}
\hline Frequency & percent & Valid percent & Cumulative percent & \\
\hline 1 & 10.0 & 11.1 & 11.1 & low \\
3 & 30.0 & 33.3 & 44.4 & low \\
3 & 30.0 & 33.3 & 77.8 & high \\
2 & 20.0 & 22.2 & 100.0 & high \\
9 & 90.0 & 100.0 & & Total \\
1 & 10.0 & & & System Missing \\
10 & 100.0 & & & Total \\
\hline
\end{tabular}

Table $20-$ Q18

\begin{tabular}{|l|l|l|l|l|}
\hline Frequency & percent & Valid percent & Cumulative percent & \\
\hline 4 & 40.0 & 40.0 & 40.0 & low \\
3 & 30.0 & 30.0 & 70.0 & high \\
3 & 30.0 & 30.0 & 100.0 & high \\
10 & 100.0 & 100.0 & & Total \\
\hline Table 21- Q19 & percent & Valid percent & Cumulative percent & \\
\hline Frequency & 10.0 & 10.0 & 10.0 & low \\
\hline 1 & 20.0 & 20.0 & 30.0 & low \\
2 & 70.0 & 70.0 & 100.0 & high \\
7 & 100.0 & 100.0 & & Total \\
10 &
\end{tabular}

Table 22-Q20

\begin{tabular}{|l|l|l|l|l|}
\hline Frequency & percent & Valid percent & Cumulative percent & \\
\hline 1 & 10.0 & 10.0 & 10.0 & low \\
4 & 40.0 & 40.0 & 50.0 & low \\
3 & 30.0 & 30.0 & 80.0 & high \\
2 & 20.0 & 20.0 & 100.0 & high \\
10 & 100.0 & 100.0 & & Total \\
\hline
\end{tabular}


Tables 15-22 are about part C (Follow-up Tasks) of the checklist. Question 13 displays $80 \%$ of high points. Q14 and Q20 have 50\% high and 50\% low. Q15 and Q18 showed 60\% high points while Q16 had 60\% low. Q17 presents 50\% high and $40 \%$ low and one missing answer. 70 percent of the participants selected high points for Q19.

Table 23 - Part C. Fallow-up Tasks (Post-listening)

\begin{tabular}{|l|l|l|l|l|l|l|l|l|}
\hline Q13 & Q14 & Q15 & Q16 & Q17 & Q18 & Q19 & Q20 & \\
\hline 10 & 10 & 10 & 10 & 9 & 10 & 10 & 10 & valid \\
0 & 0 & 0 & 0 & 1 & 0 & 0 & 0 & Missing \\
2.8000 & 2.5000 & 2.5000 & 2.5000 & 2.6667 & 2.9000 & 2.6000 & 2.6000 & Mean \\
.42164 & .52705 & .70711 & .70711 & 1.00000 & .87560 & .69921 & .96609 & Std. \\
2.00 & 2.00 & 1.00 & 2.00 & 1.00 & 2.00 & 1.00 & 1.00 & Deviation \\
3.00 & 3.00 & 3.00 & 4.00 & 4.00 & 4.00 & 3.00 & 4.00 & Minimum \\
28.00 & 25.00 & 25.00 & 25.00 & 24.00 & 29.00 & 26.00 & 26.00 & Maximum \\
& & & & & & & & Sum \\
\hline
\end{tabular}

According to the last table (table 23) the highest Means belong to question number 18 (2.9) and question 13 (2.8). However questions 14, 15, 16 have the least Means (2.5).The analysis of questions 21 and 22 of the checklist are not in the shape of tables, thus the researcher measured them qualitatively. For question number 21, most of the participants chose item $\mathrm{C}$ and none of them picked out item A. In question 22, most of the answers were to item C.

\section{Discussion}

The findings of present study demonstrated weak and strong aspects of Listening Comprehension parts in Top Notch 2A \& 2B. In part A of the checklist (Generally Questions), 80 percent of participants asserted that the pictures and visuals are not clear enough to enhance students' motivation and interest. Half of the participants emphasized that the topics are familiar and real-life. $60 \%$ of teachers stated that Listening Comprehension parts progress from simple to more complex through the Book, also these parts improve vocabulary, grammar knowledge, and dictation of students. But they claimed that the audio is not completely suitable for students' English level. And about Pre-Listening parts, they did not accept these parts provide enough words to make comprehension possible.

In part B of the checklist (Activities \& Tasks), the Tasks are introduced thoroughly for students. However $60 \%$ of participants expressed the activities are not relevant to background knowledge of students, and are not giving enough opportunities for practice.

About Follow-up Tasks (Post-listening) in part $\mathrm{C}$ of the checklist, most of the teachers confirmed the Follow-up activities have integrated Language skills, Pair work and Group work reduce shyness and fear of learners, and Role plays are based on real-life communications. On the other hand $60 \%$ of teachers believed the Discussion parts have not careful choice of topics and tasks to stimulate students' talking. In the last two questions of the checklist, the researcher asked the participants to determine which one has the key role in success of students: the Book or the teachers' creativity \& imagination. Regarding this question, the results showed that both the teacher and the Book simultaneously affect students' success in Listening Comprehension. The last question researched the function of teachers (teach students to listen for meaning rather than Language or try reducing learners' fear \& anxiety) in Listening comprehension Tasks. Most of participants believed in both of functions.

\section{Conclusion}

As it is obvious from the gathering information, the pictures and visuals of Listening Comprehension parts are not clear to increase learners' motivation and interest. Also the audio is not totally suitable for students' English level. On the other hand, the teachers are satisfied with all kinds of Follow-up Tasks except the Discussion parts which do not encourage students to talk. As Chastain (1988) stated that listening comprehension skills are prerequisite for speaking skills (p.192). Thus well-organized Discussion parts increase students' speaking abilities.

It is not just the course book which determines the achievement of students in language learning and enhancing listening comprehension skills, additionally the teachers' creativity and imagination have crucial roles. It is the duty of teachers to carefully introduce the topics, tasks and assignments for learners. Other functions of teachers are to teach students to listen for meaning (concept) rather than language, and try to reduce students' fear and anxiety. (Chastain, 1988, p. 208). As the findings of this study proved these significant teachers' functions, this present research indicated the importance of Pre-Listening activities in developing listening comprehension abilities of students. Students need to know vocabulary items (just key words) and linguistic features for comprehending the meaning in any listening comprehension task. Therefore, it emphasizes the considerable influence of teachers over what is taught in PreListening parts.

\section{References}

Chastain, K. (1988). Developing Second Language skills, Theory and Practice. San Diego: Harcourt, Brace Jovanovich. Miekley, J. (2005). ESL textbook evaluation checklist. The Reading Matrix, 5(2).

Mohammadi, M., \& Abdi, H. (2014). Textbook Evaluation: A Case Study. Procedia-Social and Behavioral Sciences, 98, 1148-1155.

Mukundan, J., Hajimohammadi, R., \& Nimehchisalem, V. (2011). Developing an English language textbook evaluation checklist. Contemporary Issues in Education Research (CIER), 4(6), 21-28. 
Nation, I.S.P., \& Macalister, J. (2010). Language Curriculum Design. CPI Group (UK) Ltd.

Rezaee, A. A., Kouhpaeenejad, M. H., \& Mohammadi, A. (2013). Iranian EFL learners' perspectives on New Interchange series and Top-Notch series: A comparative study. Procedia-Social and Behavioral Sciences, 70, 827-840.

Richards, J.C., \& Schimdt, R. (2002). Longman Dictionary of language teaching \& Applied Linguistics.

Saricoban, A., \& Can, N. (2013). An evaluation of the $9^{\text {th }}$ grade local and the international English course books in terms of language skills and components.

Saslow, J., \& Asher, A. (2006). Top Notch (2 ${ }^{\text {nd }}$ Ed.). Pearson Education, Inc.

Ur, P. (2012). A course in English language Teaching. Cambridge University Press.

\section{Appendix}

The aim of this research is to evaluate Top Notch 2A \& 2B (2006). Please answer the following questions carefully.

\section{Please first fill out this part.}

Gender: $\quad$ Male $\square \quad$ Female $\square$

Age: ................

Teaching Experience:

Listening comprehension parts

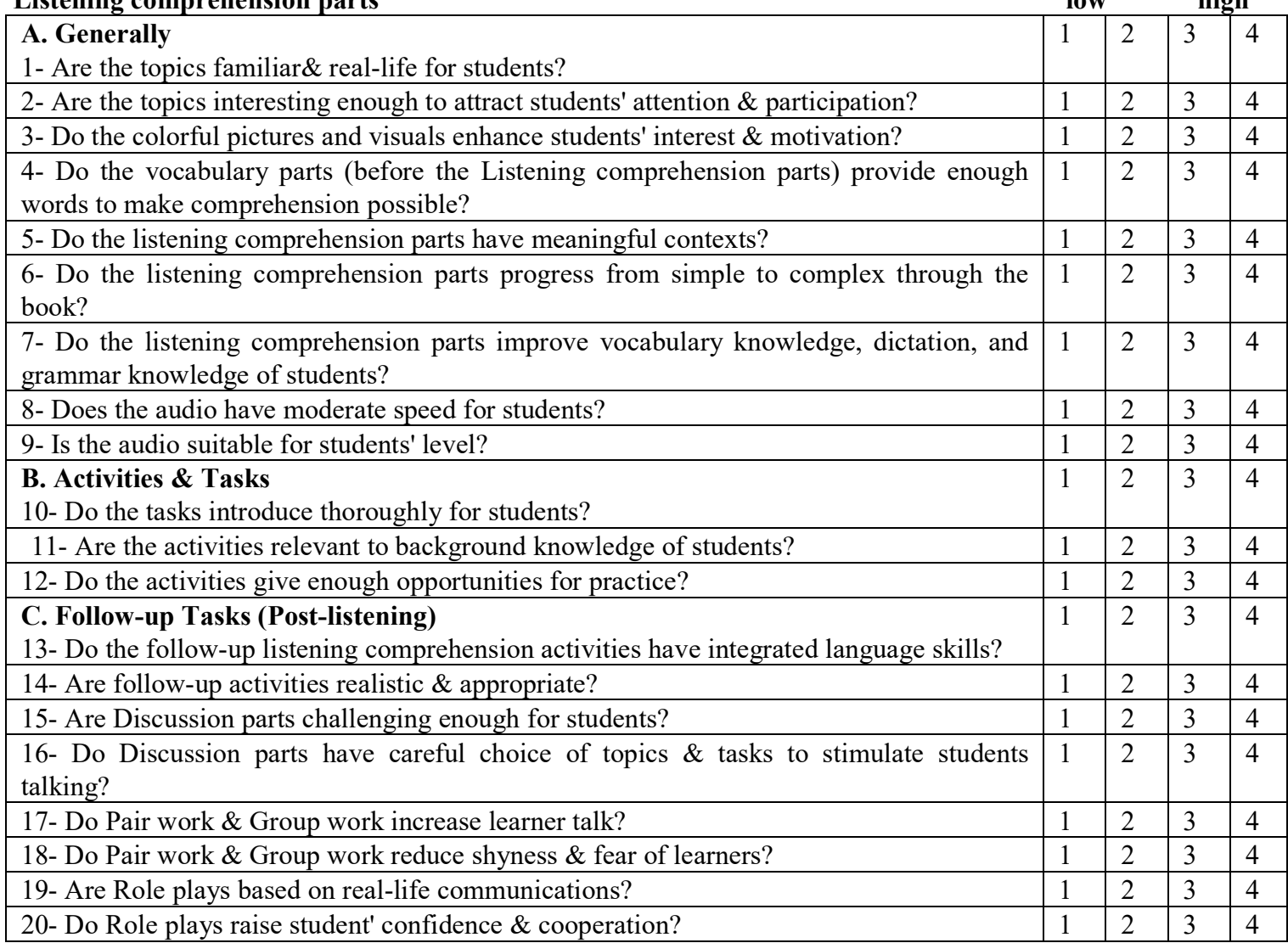

Please choose one of the items:

21- Which of the following items play a key role in success of students in listening comprehension?

A) Teachers' creativity and imagination (stimulate attention, motivation and participation of learners)

B) The book (providing familiar \& interesting topics, well-organized pre-listening \& post-listening activities for learners)

C) Both

22- How can the teachers help students to progress in listening comprehension tasks?

A) Teach them to listen for meaning (concept) rather than language.

B) Try reducing their fear and anxiety.

C) Both 